University of Nebraska - Lincoln

DigitalCommons@University of Nebraska - Lincoln

US Department of Energy Publications

U.S. Department of Energy

2003

\title{
Microbial Reduction of Structural Fe(III) in Illite and Goethite
}

Hailiang Dong

Miami University, dongh@muohio.edu

Ravi K. Kukkadapu

Pacific Northwest National Laboratory, ravi.kukkadapu@pnl.gov

James K. Fredrickson

Pacific Northwest National Laboratory, jim.fredrickson@pnl.gov

John M. Zachara

Pacific Northwest National Laboratory

David W. Kennedy

Pacific Northwest National Laboratory

See next page for additional authors

Follow this and additional works at: https://digitalcommons.unl.edu/usdoepub

Part of the Bioresource and Agricultural Engineering Commons

Dong, Hailiang; Kukkadapu, Ravi K.; Fredrickson, James K.; Zachara, John M.; Kennedy, David W.; and Kostandarithes, Heather M., "Microbial Reduction of Structural Fe(III) in Illite and Goethite" (2003). US Department of Energy Publications. 147.

https://digitalcommons.unl.edu/usdoepub/147

This Article is brought to you for free and open access by the U.S. Department of Energy at DigitalCommons@University of Nebraska - Lincoln. It has been accepted for inclusion in US Department of Energy Publications by an authorized administrator of DigitalCommons@University of Nebraska - Lincoln. 


\section{Authors}

Hailiang Dong, Ravi K. Kukkadapu, James K. Fredrickson, John M. Zachara, David W. Kennedy, and Heather M. Kostandarithes 


\section{Microbial Reduction of Structural $\mathrm{Fe}(\mathrm{III})$ in Illite and Goethite}

HAILIANG DONG, *, †

RAVI K. KUKKADAPU, $\neq$

JAMES K. FREDRICKSON,

JOHN M. ZACHARA,

DAVID W. KENNEDY, $\neq$ AND

HEATHER M. KOSTANDARITHES

Department of Geology, Miami University,

Oxford, Ohio 45056, Pacific Northwest National Laboratory,

Richland, Washington 99352

Microbial reduction of $\mathrm{Fe}(\mathrm{III})$ in illite was studied to evaluate the possibility of mic robial utilization of $\mathrm{Fe}(\mathrm{III})$ in sedimentary clays and to determine the effects of bioreduction on clay composition and structure. A subsurface bacterium (Shewanella putrefaciens CN 32) and illite separates $(<0.2 \mu \mathrm{m})$ from St. Peter Formation sandstone in Ogle County, IL, were used in laboratory experiments. Illite suspensions buffered at pH 7 with bicarbonate were inoculated with $\mathrm{CN} 32$ and provided with $\mathrm{H}_{2}$ as an electron donor. In selected treatments, anthraquinone-2,6-disulfonate (AQDS), was included as an elec tron shuttle to facilitate the bioreduction. Fe(II) production in inoculated treatments was determined by extraction with $0.5 \mathrm{~N} \mathrm{HCl}$ and compared to uninoculated controls to establish the extent of biological reduction. The resulting solids were characterized by Mossbauer spectroscopy and scanning and transmission electron microscopy (SEM and TEM ). The characterization of the starting illite material revealed that it contained a minor component of goethite $(\alpha-\mathrm{FeOOH})$ in addition to fibrous illite. The starting material (both goethite and illite) contained $6 \%$ (w/ W) total Fe, and $82 \%$ of the total Fe was Fe(III). A pproximately $30 \%$ of total Fe was associated with goethite. At the end of a 30-day incubation, residual goethite and illite remained. The extent of reduction was much greater in the presence of AQDS (25\%) than in its absence (0\%). M odeling of M ossbauer spectra of the bioreduced material indicated that both goethite and illite were reduced but to a different extent. Additionally, TEM evidence suggested that there was a dramatic change in illite morphology upon bioreduction from fibrous needles to plates. The ability of bacteria to utilize Fe(III) in illite has important implications for microbial functions and survival mechanisms, as well as many geological processes, in the subsurface.

\section{Introduction}

Smectite-illite clay minerals are ubiquitous in natural sediments, soils, and sedimentary rocks, and they play an important role in a number of environmental processes, including nutrient cycling, plant growth, contaminant migration, organic matter maturation, and petroleum migration. The extent and the rate that smectite-illite minerals affect

\footnotetext{
*Corresponding author phone: (513) 529-2517; fax: (513) 5291542; e-mail: dongh@muohio.edu.

$\uparrow$ Miami University.

¥ Pacific Northwest National Laboratory.
}

these environmental processes are largely determined by their physical and chemical properties, which arecorrelated with the oxidation state of Fe in their structures $(1,2)$. Although the oxidation state of Fein smectite-illite minerals can be altered by abiotic reactions, the role that microbes play in cycling Fe oxidation states has become increasingly recognized. Indeed, microbes and clay minerals can coexist in a number of geological environments ranging from surface soils to sandstones, siltstones and shales at great depth (up to $2700 \mathrm{~m}$ below the land surface), and high temperatures (up to $\left.90-100^{\circ} \mathrm{C}\right)(3-6)$. The closecontact between microbes and clay minerals provides ample opportunities for their mutual interactions, where clays may provide nutrients and habitats for microbes, and microbes may influence clay mineral reactions.

Recent studies have shown that several bacteria are capable of reducing structural Fe(III) in smectite $(2,7,8)$, resulting in changes in physical and chemical properties of smectite. Thesestudies have been primarily concerned with expandable smectite, and no attempt has been madeto study other types of clays. When water-bearing and expandable smectite is buried and subjected to increasing temperature and pressure, it tends to transform to other types of clays, of which illite is the most abundant $(9,10)$. The resultant illite is fundamentally different in both structure and composition from smectite. We have yet to show if ferric iron in well-ordered illite is accessible to bacteria.

Unlike smectite, which is present in surface soils and unconsolidated sediments at shallow depths, illite is ubiquitous in diverse geological environments, ranging from soils to consolidated sedimentary rocks (such as shales, siltstones, and sandstones) at great depths. Because of widespread occurrences of illite in nature, microbe-illite interactions could haveimportant implications for a number of geological processes. For example, becauseilliteformation significantly diminishes rock pore space, thus reducing the storage capacity of hydrocarbons in sandstones, microbial impact on illite precipitation and dissolution rates needs to be included when a basin scale clay transformation (i.e., smectite-illite) model is developed (11), which would have important implications for organic matter maturation and petroleum migration.

The goals of this study were to evaluate the microbial reduction of $\mathrm{Fe}(\mathrm{III})$ in illite and to determine the effects of microbial reduction on illite structure and composition. We used Shewanella putrefaciensstrain CN32, a metal-reducing bacterium isolated from the Morrison Formation in New Mexico. Wehaveinvestigated theinfluence of anthraquinone2,6-disulfonate (AQDS), a naturally present humic acid analogy and an electron shuttle for microbial Fe(III) reduction, on the rate and the extent of illite reduction. We used chemical extraction methods and Mössbauer spectroscopy to measure $\mathrm{Fe}(\mathrm{II})$ production and to characterize the distribution of Fe(II) and Fe(III) in unreduced and bioreduced suspensions. Transmission electron microscopy (TEM) was used to probe the morphology of the solids following microbial reduction of illite.

\section{Materials and Methods}

Bacteria, Media, and Mineral. S. putrefaciens strain CN32 was provided courtesy of Dr. David Boone (Portland State University, Portland, OR). Strain CN32 was isolated from a subsurface core sample from the Morrison Formation (250 $m$ beneath the surface) during drilling of a shale-sandstone sequence in northwestern New Mexico. CN32 was routinely cultured aerobically in tryptic soy broth (TSB), $30 \mathrm{~g} / \mathrm{L}$ (Difco 
Laboratories, Detroit, MI), and stock cultures were maintained by freezing in $40 \%$ glycerol at $-80^{\circ} \mathrm{C}$.

The illite used in this study was kindly provided by Dr. Randall Hughes at the Illinois State Geological Survey. Illite powder of $<0.2 \mu \mathrm{m}$ was separated from a sandstone sample by repeated gravity settling and centrifugation. The sandstone sample was of Ordovician age, and was collected from an outcrop of St. Peter Formation in Ogle County, IL. The illite separates were green in color. The $<0.2 \mu \mathrm{m}$ separates were characterized by chemical extractions to determine thetotal Fe content and $\mathrm{Fe}(\mathrm{II}) / \mathrm{Fe}(\mathrm{III})$ ratio, and by X-ray diffraction (XRD) and TEM to identify mineralogy. In addition to illite, there was a small amount of goethite (see below). The sample is hereafter referred to as the starting material.

The components in the defined solutions used for the reduction experiments were composed of Fe (III) in goethite and illite as electron acceptors, $\mathrm{H}_{2}$ as an electron donor, and CN32 cells. The solutions were buffered with bicarbonate ( $\mathrm{pH} \sim 7$ ). The bicarbonate buffer was made of $2 \mathrm{~g} / \mathrm{L}$ of reagent grade $\mathrm{NaHCO}_{3}$, and $0.08 \mathrm{~g} / \mathrm{L}$ of $\mathrm{KCl}$. In select treatments, AQDS (Sigma, St. Louis, MO) was added separately.

Bacterial Reduction Experiments. Separates of the starting material were made into slurry with bicarbonate buffer (clay concentration in slurries was $\sim 100 \mathrm{mg} / \mathrm{mL}$ ). Thisslurry served as a stock solution for subsequent treatments and was pasteurized in a $90{ }^{\circ} \mathrm{C}$ water bath for $0.5 \mathrm{~h}$ on two consecutive days. In a typical experiment with $10 \mathrm{~mL}$ final volume of culture medium, $1 \mathrm{~mL}$ of clay slurry (final concentration, $10 \mathrm{mg} / \mathrm{mL}$ ) was added to replicate pressure tubes of 25- $\mathrm{mL}$ capacity, followed by addition of $0.1 \mathrm{~mL}$ of $10 \mathrm{mM}$ AQDSin select treatments, and $8-9 \mathrm{~mL}$ of bicarbonate buffer. In those treatments without AQDS, an equivalent volume of bicarbonate buffer was added in place of AQDS. Tubes were purged with $\mathrm{N}_{2} / \mathrm{CO}_{2}$ gas mix (80:20) and sealed with thick butyl rubber stoppers. One $\mathrm{mL}$ of CN32 cell suspension was added from a freshly washed culture $(8 \times$ $10^{7}$ cells/ mL, final concentration) in bicarbonate buffer by using a sterile needle and syringe. The control consisted of one tube that received $1 \mathrm{~mL}$ of sterile bicarbonate buffer in place of CN32 cells. Last, $10 \mathrm{~mL}$ of $\mathrm{H}_{2}$ gas was added to the treatment tubes. All experiments were incubated at $30^{\circ} \mathrm{C}$ with shaking at $30 \mathrm{rpm}$ for 30 days.

Analyses. The starting material was dissolved in $0.5 \mathrm{~N}$ $\mathrm{HF}$, and its Fe(II) content was determined by ferrozine assay (12). Total Fe was determined by reducing Fe(III) to Fe(II) with hydroxylamine $\mathrm{HCl}$, followed by ferrozineassay. To detect amorphous Feoxides, thestarting material was extracted with ammonium oxalate (13). The ammonium oxalateextracted solids were analyzed by Mössbauer spectroscopy.

The extent of microbial reduction of goethite and illite was monitored by measuring Fe(II) production. At select time points, $0.5 \mathrm{~mL}$ of cell-mineral suspension, sampled with a sterile syringe, was added to plastic tubes preadded with 0.5 $\mathrm{mL}$ of $1 \mathrm{~N}$ Ultrex $\mathrm{HCl}$. The cell-mineral suspension was allowed to stand in $\mathrm{HCl}$ for $24 \mathrm{~h}$ before analyzing for $\mathrm{Fe}(\mathrm{II})$. This extraction is termed the $0.5 \mathrm{~N} \mathrm{HCl}$ extraction, and has been shown to be effective for extracting microbially produced $\mathrm{Fe}(\mathrm{II})$ including adsorbed form and $\mathrm{Fe}(\mathrm{II})$ in biogenic solids except for highly crystalline magnetite (14, 15). The concentrations of aqueous Fe(II), as well as other ions, were determined at the final time point ( 30 days) by filtering $1 \mathrm{~mL}$ of suspension through a $0.2-\mu \mathrm{m}$ polycarbonate filter into $1 \mathrm{~mL}$ of $1 \mathrm{~N}$ Ultrex $\mathrm{HCl}$. Residual solids at the final time point were extracted with ammonium acetate solution under anaerobic conditions to determine surface-adsorbed Fe(II) (16). A ferrozineassay was performed to measureFe(II) concentration in all of the extracts (ammonium oxalate, 0.5 $\mathrm{N} \mathrm{HCl}$ extracts, and ammonium acetate) and the aqueous fraction. Concentrations of total Feand other major elements of illite and goethite, $\mathrm{Mg}, \mathrm{Al}$, and $\mathrm{Si}$, were determined by ICPMS.

Chemical Reduction Experiment. To providea reference point for the microbial reduction experiment, the starting and bioreduced materials were also extracted with a dithionite-citrate-bicarbonate (DCB) solution (anaerobic $0.3 \mathrm{M}$ Na citrate, $1 \mathrm{~mL} 1 \mathrm{M}$ anaerobic bicarbonate, and $200 \mathrm{mg} \mathrm{Na}$ dithionite) overnight in a $30^{\circ} \mathrm{C}$ incubator with shaking (25 rpm). TheDCB extraction was repeated, and the concentrated solids were washed twice in anaerobic $0.1 \mathrm{M}$ sodium perchlorate solution and once in anaerobic $30 \mathrm{mM}$ bicarbonatesolution. TheDCB-extracted pellets were resuspended in $10 \mathrm{~mL}$ anaerobic $30 \mathrm{mM} \mathrm{HCO}_{3}$ solution and prepared for Mössbauer spectroscopy.

Mossbauer Spectroscopy. ${ }^{57} \mathrm{Fe}$ transmission Mössbauer spectroscopy was employed to characterizethe Fe mineralogy of the starting material and the nature of the bioreduced minerals. Mössbauer spectroscopy is a very sensitive and Fe-specific technique. For the unreduced material, both room temperature (RT) and $77 \mathrm{~K}$ spectra were obtained. The $77 \mathrm{~K}$ Mössbauer spectrum was obtained for the bioreduced material at the final time point (30 days). The bioreduced sample was analyzed under anaerobic conditions in an environmental chamber. Details of theinstrumentation, data collection, calibration, and folding of the data have been described elsewhere $(17,18)$. For measurements at liquid nitrogen temperature $(77 \mathrm{~K})$, only the absorber was at this temperature, and both the source and drive assemblies were still at room temperature. All Mössbauer spectra were fitted with quadrupole splitting distribution (QSDs) or hyperfine splitting distributions (HFDs) using the Voigt-based fitting method (19). The following guidelines were used in the modeling of the Mössbauer data: (1) the Lorentzian halfwidth at full maximum (HWFM) was fixed at the known Heisenberg value of $0.097 \mathrm{~mm} / \mathrm{s}$; (2) only symmetric doublets and sextets were used; (3) neither coupling of $d$ or center shift (CS) with the distributed hyperfine parameter (D or QS) nor coupling of e with the distributed hyperfine parameters (z) was allowed.

X-ray Diffraction. Powder XRD patterns were obtained with a Philips PW3040/00 X'Pert MPD system, using CuK $\alpha$ radiation with a variable divergent slit and a solid-state detector. The routine power was $700 \mathrm{~W}$ (35 kV, $20 \mathrm{~mA})$. Lowbackground quartzXRD slides (Gem Dugout, Inc., Pittsburgh, PA) were used. For analysis, powder samples were tightly packed into the well of the slides (1/4-in. diameter).

Fixation, Dehydration, and Embedding for TEM Observations. At select time points (0, 2, 7, and 30 days), a small amount of sample slurry $(1 \mathrm{~mL})$ was removed from each treatment tube and fixed in $2.5 \%$ glutaral dehyde for at least 1 day. Because of concerns of decanting fine particles during subsequent dehydration steps, fine mineral particles were initially gently settled to the bottom of an eppendorf tube using a combination of gravity settling and slow speed centrifugation (several $\mathrm{g}$ forces). The semiconsolidated material was then encapsulated in $4 \%$ agar (w/w), and solidified agar (with encapsulated particles) was cut with a razor blade to form agar cubes of $2-3 \mathrm{~mm}$ in size. The cubes were then placed in glass vials filled with $0.05 \mathrm{M}$ sodium cacodylate buffer $(\mathrm{pH}=7)$. The cubes were rinsed with sodium cacodylate buffer 4 times, followed by the secondary fixation with $1 \%(\mathrm{w} / \mathrm{w})$ osmium tetroxide $\left(\mathrm{OsO}_{4}\right)$ in the buffer for $2-3 \mathrm{~h}$. The $\mathrm{OsO}_{4}$-fixed cubes were rinsed with distilled water 4 times, followed by staining with $0.05 \%(w / w)$ uranyl acetate overnight. The cubes were rinsed with distilled water 4 times, followed by dehydration through grade series of ethanol and embedded in L. R. White resin (Electron Microscopy Sciences, Fort Washington, PA). Ultrathin sections (50-100 nm) were cut with a diamond knife using a Reichert Ultracut E ultramicrotomeand coated with gold for 

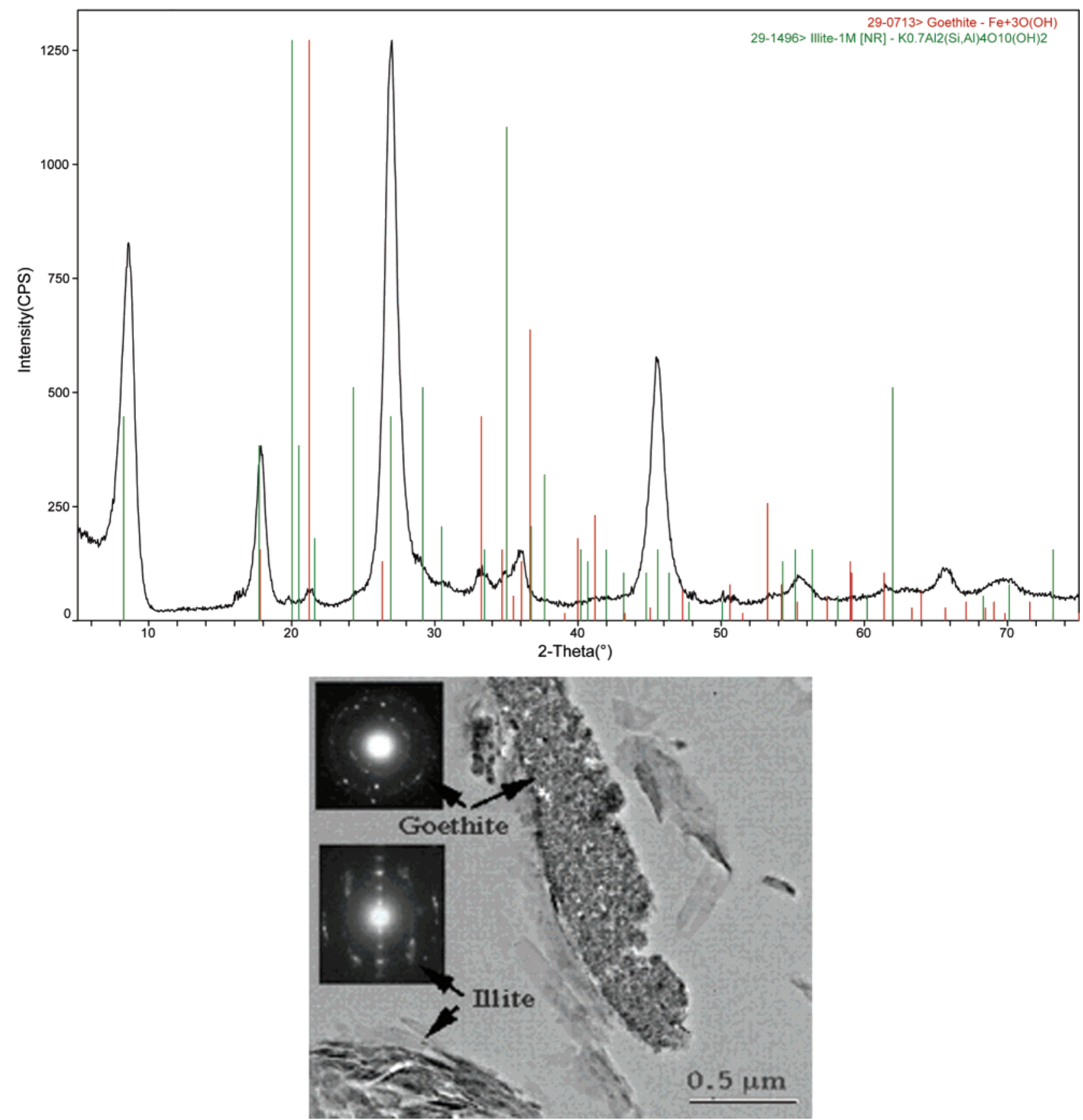

FIGURE 1. (a) XRD pattern of the starting material showing that it is dominated by illite with a minor amount of goethite. Black trace, experimental pattern; red vertical lines, standard goethite pattern; green vertical lines, $1 \mathrm{M}$ illite pattern. (b) TEM image and corresponding selected area electron diffraction (SAED) patterns show ing illite and goethite. Fine-grained goethite particles aggregate to form irregularly shaped assemblages.

TEM observations. To observe change of morphology of goethiteand illite particles as a result of microbial reduction, mineral particles from the starting and bioreduced samples were also directly mounted onto holey carbon Cu grids. The grids weresubsequently carbon-coated for TEM observations.

TEM Observations. Ultrathin sections were examined using a Zeiss $10 \mathrm{C}$ TEM with an $80 \mathrm{kV}$ operating voltage. Highresolution lattice fringe imaging and chemical analyses were performed with a Philips CM 12 scanning transmission electron microscopy (STEM) fitted with a Kevex Quantum solidstate detector and computer system. The STEM wasoperated at $120 \mathrm{kV}$ and a beam current of $20 \mu \mathrm{A}$. A camera length of $770 \mathrm{~nm}$ and a selected area aperture $10 \mu \mathrm{m}$ in diameter were used to obtain selected area electron diffraction (SAED) patterns. Quantitative energy dispersive spectrum (EDS) chemical analyses were obtained in scanning mode by using a beam diameter of $50 \AA$ and a scanning area of $300 \times 300$ $\AA$. Standards and other conditions used were similar to those defined previously (9). The mineral-particle-mounted $\mathrm{Cu}$ grids were also observed with the Philips CM12 STEM for morphology, electron diffraction, and chemical analyses.

\section{Results}

Characteristics of IlliteSample. The HF extraction indicated that the starting material contained $6 \%$ total Fe by weight and that most of the Fe was present as Fe(III) (82\%). XRD identified the starting material as illite with a minor amount of goethite $(<5 \%$ ) (Figure 1a). SAED patterns confirmed the 
TABLE 1: Calculated $77 \mathrm{~K}$ Mössbauer Parameters ${ }^{\mathrm{a}}$

\begin{tabular}{|c|c|c|c|c|c|c|c|c|c|}
\hline sample & Fe mineral & $\begin{array}{c}\langle\mathrm{CS}\rangle \\
(\mathrm{mm} / \mathrm{s})\end{array}$ & $\langle\mathbf{Q S}\rangle$, & $\begin{array}{c}\sigma_{\mathrm{QSD}} \\
(\mathrm{mm} / \mathrm{s})\end{array}$ & $\begin{array}{c}\langle\mathbf{e}\rangle \\
(\mathrm{mm} / \mathrm{s})\end{array}$ & $\begin{array}{l}\left\langle\mathbf{B}_{\mathrm{hf}}\right\rangle \\
\text { tesla }\end{array}$ & $\begin{array}{l}\sigma_{\text {HFD }} \\
\text { tesla }\end{array}$ & $\begin{array}{c}\text { area } \\
\%\end{array}$ & illite $\mathrm{Fe}(\mathrm{II}) / \mathrm{Fe}$ (III) ratio \\
\hline unreduced & $\begin{array}{l}\text { Al-goethite } \\
\text { illite-Fe(III) } \\
\text { illite-Fe(II)-trans } \\
\text { illite-Fe(II)-cis }\end{array}$ & $\begin{array}{l}0.482 \\
0.470 \\
1.280 \\
1.439\end{array}$ & $\begin{array}{l}0.723 \\
3.042 \\
2.033\end{array}$ & $\begin{array}{l}0.52 \\
0.193 \\
0.09\end{array}$ & -0.121 & 46.66 & 2.48 & $\begin{array}{r}29 \\
58 \\
11 \\
2\end{array}$ & 0.22 \\
\hline bioreduced(with AQDS) & $\begin{array}{l}\text { Al-goethite } \\
\text { illite-Fe(III) } \\
\text { illite-Fe(II)-trans } \\
\text { illite-Fe(II)-cis }\end{array}$ & $\begin{array}{l}0.467 \\
0.451 \\
1.254 \\
1.365\end{array}$ & $\begin{array}{l}0.717 \\
2.983 \\
1.999\end{array}$ & $\begin{array}{l}0.521 \\
0.23 \\
1.99\end{array}$ & -0.156 & 47.48 & 1.58 & $\begin{array}{r}17 \\
59 \\
22 \\
3\end{array}$ & $0.43^{b}$ (non-Fe oxide) \\
\hline reoxidized & $\begin{array}{l}\text { Al-goethite } \\
\text { illite-Fe(III) } \\
\text { illite-Fe(II)-trans } \\
\text { illite-Fe(II)-cis }\end{array}$ & $\begin{array}{l}0.485 \\
0.473 \\
1.267 \\
1.348\end{array}$ & $\begin{array}{l}0.716 \\
3.02 \\
1.984\end{array}$ & $\begin{array}{l}0.72 \\
3.02 \\
1.98\end{array}$ & -0.111 & 47.02 & 1.91 & $\begin{array}{r}17 \\
67 \\
15 \\
2\end{array}$ & 0.28 (illite ratio) \\
\hline \multirow{2}{*}{$\begin{array}{l}\text { bioreduced } \\
\text { DCB-treated }\end{array}$} & illite-Fe(III) & 0.475 & 0.704 & 0.54 & & & & 79 & \\
\hline & illite-Fe(II) & 1.260 & 3.028 & 0.24 & & & & 21 & 0.27 \\
\hline
\end{tabular}

a $\langle\mathrm{CS}\rangle=$ average center shift, $\langle\mathrm{QS}\rangle=$ average quadrupole shift, $\sigma_{\mathrm{QSD}}=$ standard deviation of QSD, $\langle\epsilon\rangle=$ average quadrupole shift parameter, $B_{\mathrm{hf}}=$ magnetic field, $\sigma_{\mathrm{HFD}}=\mathrm{std}$ dev of HFD. ${ }^{b}$ Not illite Fe(II)/Fe(III) ratio. ${ }^{c}$ Calculated illite Fe(II)/Fe(III) ratio $\sim 0.28$.

presence of illite and goethite (Figure 1b). TEM bright field imaging showed that goethite was fine-grained, and SAED patterns displayed powder-like, diffuse rings, suggesting small crystal sizes (on the order of nanometers) and poor crystallinity. Illite displayed $1 \mathrm{M}$ polytype, $10-\AA$ lattice fringes with crystallites 10-20nm in thickness. EDS analyses determined theillite composition as $\left(\mathrm{Na}_{0.12} \mathrm{~K}_{1.34}\right)\left(\mathrm{Mg}_{0.48} \mathrm{Fe}_{1.32} \mathrm{Al}_{2.18}\right)\left(\mathrm{Al}_{0.48^{-}}\right.$ $\left.\mathrm{Si}_{7.52}\right) \mathrm{O}_{20}(\mathrm{OH})_{4}$. EDS analyses of goethite identified some Al substitution for Fe. The ammonium oxalate extraction indicated that the amount of amorphous Fe oxide was negligible (data not shown).

Mössbauer spectroscopy revealed that the room-temperature spectrum of the starting material displayed two doublets, an intense central doublet $(\sim 0.48 \mathrm{~mm} / \mathrm{sec})$ due to $\mathrm{Fe}^{3+}$ (illite-associated $\mathrm{Fe}^{3+}+$ small particle goethite) and a side doublet due to illite-associated $\mathrm{Fe}^{2+}(\sim 2.5 \mathrm{~mm} / \mathrm{sec})$. To resolve illite $\mathrm{Fe}^{3+}$ and goethite $\mathrm{Fe}^{3+}$, a $77 \mathrm{~K}$ measurement was performed. An intense sextet was evident in the $77 \mathrm{~K}$ spectrum, characteristic of Al-substituted, small particle goethite (18). The Mössbauer parameters for the starting (unreduced) material are shown in Table 1. Modeling of the $77 \mathrm{~K}$ experimental spectrum determined the relative proportions of the total $\mathrm{Fe}$ in goethite $(29 \%)$, illite-associated $\mathrm{Fe}^{3+}$ (58\%), and illite-associated $\mathrm{Fe}^{2+}(13 \%)$ with the $\mathrm{Fe}(\mathrm{II}) / \mathrm{Fe}(\mathrm{III})$ ratio of illite equal to 0.22 contributing to the $\mathrm{Fe}_{T}$ (Figure $2 \mathrm{~b}$ ). Although goethite was a minor component in the starting material on a mass basis $(<5 \%)$, it contained a significant proportion of the total $\mathrm{Fe}(29 \%)$. The relative proportion of $\mathrm{Fe}^{3+}$ as determined by Mössbauer spectroscopy (29\%+58\% $=87 \%$ ) is consistent with that determined by the chemical method (82\%). The Mössbauer spectrum for the starting material after extraction with ammonium oxalate was similar to that of the unextracted material, implying that poorly crystalline Fe oxides, such as ferrihydrite, were absent or only minor constituents.

Microbial Reduction of Illiteand Goethite. The presence of AQDS at $0.1 \mathrm{mM}$ greatly stimulated the reduction of Fe(III) by S. putrefaciens strain CN32, as evidenced by an increase in $\mathrm{HCl}$-extractable $\mathrm{Fe}(\mathrm{II})$ relative to the control (Figure 3). Interestingly, most of the reduction occurred between days 4 and 14. On the basis of the Fe(III) concentration of the starting material and assuming that the increase in $0.5 \mathrm{~N}$ $\mathrm{HCl}$ extractable Fe(II) was due to $\mathrm{Fe}(\mathrm{III})$ bioreduction, 25\% $\pm 3 \%$ of the Fe(III) in the starting sample had been reduced by the end of the experiment. The control without CN32 cells did not show any significant reduction (Figure 3 ). In the remainder of the text, "the bioreduced sample" refers to the
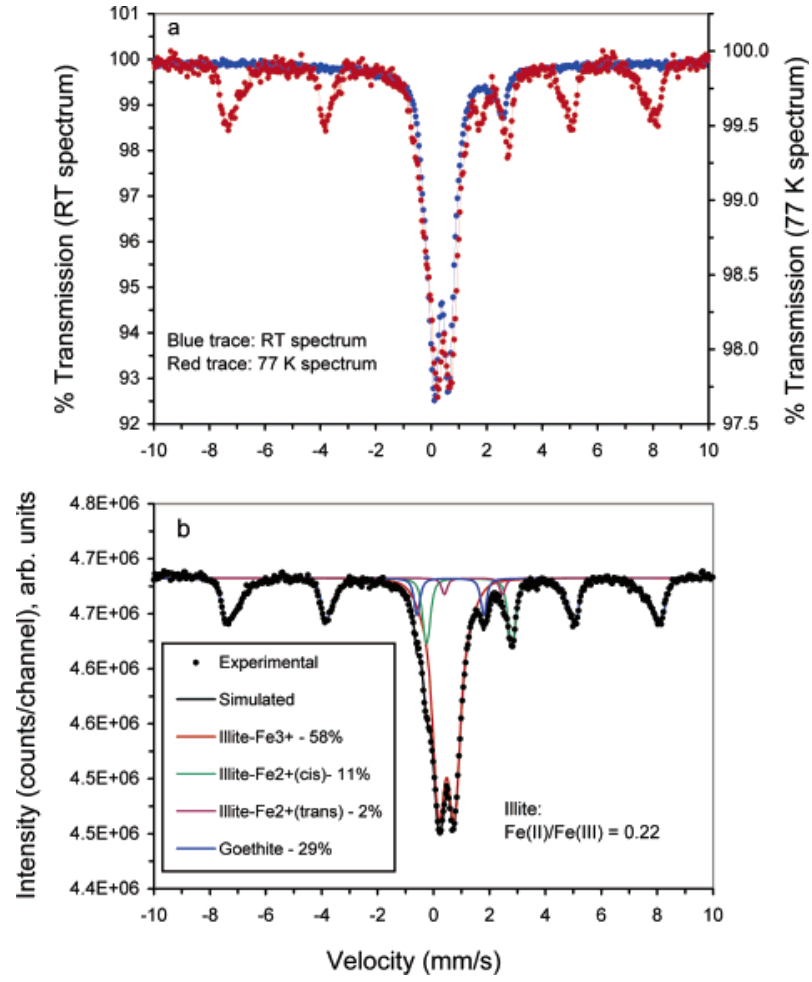

FIGURE 2. (a) Mossbauer spectrum of the starting material at room temperature and $77 \mathrm{~K}$, (b) the $77 \mathrm{~K}$ spectrum $w$ ith the modeled curve superimposed. Show $n$ in the inset box are fractions of Fe in illite and goethite obtained from modeling of the experimental spectra.

sample in the treatment with AQDS (at theend of reduction, i.e., 30 days).

The aqueous concentration of Fe(II) in the bioreduced sample comprised a significant fraction of the total $\mathrm{Fe}(\mathrm{II})$ as determined by $\mathrm{HCl}$ extraction (Table 2). The $0.5 \mathrm{~N} \mathrm{HCl}$ probably dissolved a small amount of residual illite, as evidenced by someamounts of $\mathrm{Si}, \mathrm{Al}$ and $\mathrm{Mg}$ in the $0.5 \mathrm{~N} \mathrm{HCl}$ extract (Table 2). The measured Fe concentration, thus, had to be corrected. Because both $\mathrm{Mg}$ and Fe occupy the octahedral site of the illite structure, weassumethat Mgand Fe dissolved congruently in $0.5 \mathrm{~N} \mathrm{HCl}$. On the basis of the TEM measured $\mathrm{Fe} / \mathrm{Mg}$ ratio of 2.75 , the amount of 0.03 $\mathrm{mmol} / \mathrm{g}$ of $\mathrm{Mg}$ corresponded to $0.08 \mathrm{mmol} / \mathrm{g}$ of $\mathrm{Fe}$. On the basis of Mössbauer-measured $\mathrm{Fe}(\mathrm{II}) / \mathrm{Fe}(\mathrm{III})$ of $0.27,0.08$ 
TABLE 2: Solution Compositions of Various Extracts ${ }^{\text {a }}$

$\begin{array}{cccc}\mathrm{Mg}(\mathrm{mmol} / \mathrm{g})^{b} & \text { Al }(\mathrm{mmol} / \mathrm{g})^{b} & \text { Si }(\mathrm{mmol} / \mathrm{g})^{b} & \text { Fe }(\mathrm{mmol} / \mathrm{g})^{b, c, d} \\ & & & 0.138 \pm 0.011 \\ 0.030 \pm 0.003 & 0.084 \pm 0.006 & 0.044 \pm 0.003 & 0.276 \pm 0.015 \\ & & & 0.217 \pm 0.022 \\ 0.009 \pm 0.001 & 0.001 \pm 0.0001 & 0.034 \pm 0.003 & 0.095 \pm 0.016 \\ & & & 0.107 \pm 0.008\end{array}$

aqueousFe(II), ferrozine

$0.5 \mathrm{~N} \mathrm{HCl}$, ICPMS

$0.5 \mathrm{~N} \mathrm{HCl}$, ferrozine

ammonium acetate ferrozine

ammonium acetate ICPMS

${ }^{a}$ All of these extractions were performed on the bioreduced sample (with AQDS) at the final time point. ${ }^{b}$ millimole per gram of the starting material. ${ }^{c}$ The Fe concentration extracted by ICPMS is slightly higher than that extracted by ferrozine assay, because the ICPMS analyses measured total Fe, whereas ferrozine assay measured Fe(II) only. ${ }^{d}$ The $\mathrm{Fe}$ (II) concentration as extracted by $0.5 \mathrm{~N} \mathrm{HCl}$ and ammonium acetate and measured by ICPMS is corrected for a minor contribution from illite (see text for discussion).

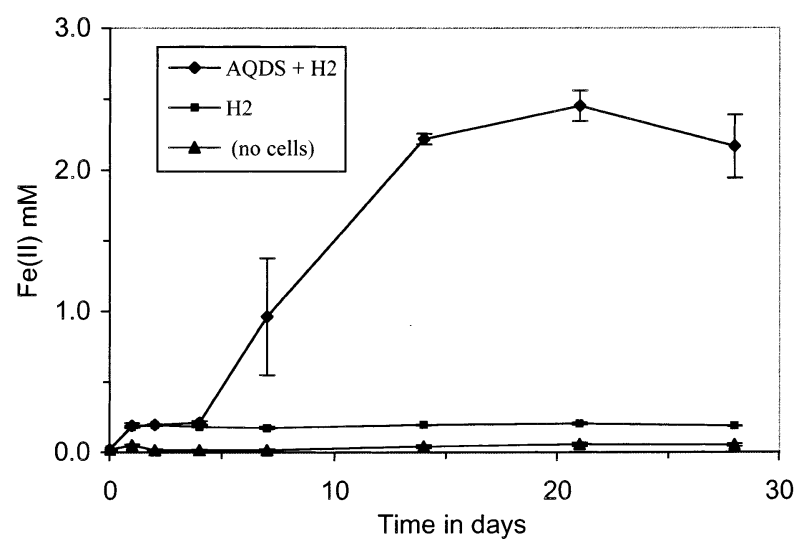

FIGURE 3. HCl-extractable Fe(II) in illite control (no cells added), in illite $+\mathrm{H}_{2}$, and in illite $+A Q D S+\mathrm{H}_{2}$. The addition of AQDS greatly enhanced the extent and the rate of microbial reduction of illite and goethite.

$\mathrm{mmol} / \mathrm{g}$ of Fe contained $0.02 \mathrm{mmol} / \mathrm{g}$ of $\mathrm{Fe}(\mathrm{II})$, and this amount was subtracted from the measured Fe (II) to give a more accurate measure of $0.5 \mathrm{~N} \mathrm{HCl}$-extractable $\mathrm{Fe}(\mathrm{II})$. Similarly, theammonium acetate probably extracted a minor amount of Fe from residual illite, and the same correction procedure was applied. Ammonium acetate extraction of the bioreduced sample indicated that a significant amount of the biogenic Fe(II) was adsorbed on the residual solids. The sum of aqueous and surface-adsorbed Fe(II) concentrations was nearly identical to $0.5 \mathrm{~N} \mathrm{HCl}$-extractable Fe(II) for the bioreduced sample ( 0.23 vs $0.22 \mathrm{mmol} / \mathrm{g}$ ) (Table 2 ).

The coexistence of illite and goethite in the starting material made it difficult to quantify the amount of Fe(III) associated with each phase that was reduced by CN32. The results of Mössbauer spectroscopy and TEM observations suggest that both goethite and illite were reduced.

Mossbauer Spectroscopy. The $77 \mathrm{~K}$ Mössbauer spectral pattern for the bioreduced material was similar to that for the starting material, suggesting that residual goethite- and illite-associated Fe remained after the bioreduction (Figure 4a). In comparison with the spectrum for the unreduced material, the sextet, the central doublet $\left(\mathrm{Fe}^{3+}\right)$, and the side doublet $\left(\mathrm{Fe}^{2+}\right)$ had similar apparent positions with similar Mössbauer parameters (Table 1), but their peak areas changed significantly. Specifically, the peak areas of the sextet and the central doublet were smaller and the side doublet, significantly larger, than the corresponding peak areas for the unreduced material. Thesechanges suggest the reduction of both goethite- (the sextet) and illite-associated $\mathrm{Fe}^{3+}$ (the central doublet) to produce biogenic $\mathrm{Fe}^{2+}$ (the side doublet). The Fe(II)/Fe(III) ratio for non-Feoxide was higher than that for the starting material ( $\sim 0.43$ vs $\sim 0.22$ ). The amount of $\mathrm{Fe}(\mathrm{II})$ increase ( $9 \%$ of total $\mathrm{Fe}$ ) due to the bioreduction as determined by Mössbauer spectroscopy (only that fraction associated with residual solids) plus aqueous fraction Fe(II)
(12\%) was nearly identical to the $\mathrm{HCl}$ extractable Fe(II) (20\% of total $\mathrm{Fe}$ ).

The $\mathrm{Fe}(\mathrm{II}) / \mathrm{Fe}(\mathrm{III})$ ratio of 0.43 for non-Fe oxide in the bioreduced sample probably did not represent illiteFealone, because the side doublet $\left(\mathrm{Fe}^{2+}\right)$ could have contributions from two sources: illite-associated $\mathrm{Fe}^{2+}$ and adsorbed $\mathrm{Fe}^{2+}$ (Figure 4b), as suggested by Diamant etal. in their Mössbauer study of kaolinite (20). To determine the $\mathrm{Fe}(\mathrm{II}) / \mathrm{Fe}(\mathrm{III})$ ratio for illite structural Fe, the surface-adsorbed fraction of Fe(II) had to be removed prior to analysis by Mössbauer spectroscopy. The bioreduced sample that was reoxidized in air for 3 weeks showed a significant decrease in the side doublet (Figure 4c). Consequently, the central doublet (illite associated and surface associated $\mathrm{Fe}^{3+}$ ) increased. It is generally accepted that the oxidation of structural Fe(II) in phyllosilicates is recal citrant to oxidation by $\mathrm{O}_{2}$ in air; thus, it can beassumed that only thesurfaceadsorbed Fe(II) was oxidized (21). Under this assumption, thepeak area of theside doublet for the reoxidized sample and that of the central doublet for the bioreduced sampleshould becharacteristic of Fe(II) and $\mathrm{Fe}(\mathrm{III})$ in illite, respectively. The resulting ratio of $\mathrm{Fe}(\mathrm{II}) /$ $\mathrm{Fe}(\mathrm{III})$ of 0.28 was significantly higher than 0.22 for the unreduced illite (Figure 2b), indicating that there was AQDSfacilitated bioreduction of illite. The ratio of 0.28 was nearly identical to the $\mathrm{Fe}(\mathrm{II}) / \mathrm{Fe}(\mathrm{III})$ ratio of 0.27 for the DCB-reduced sample (Figure 4d). The DCB extraction not only removed goethite, but also reduced illite-associated Fe(III) to Fe(II) that remained as part of the illite structure. The Mössbauer spectra for the DCB treated samples (both unreduced [data not shown] and bioreduced samples) were identical.

To adequately fit the goethite contribution to the $77 \mathrm{~K}$ spectra of the unreduced and bioreduced samples, a Gaussian component distribution was invoked. The hyperfine distribution (HFD) spectra of goethite before and after the bioreduction are shown in Figure 4e. The presence of two Gaussian components in thestarting goethite indicated that goethite existed as a range of particle sizes/crystallinity classes. The average hyperfine field of the sharp component in both the unreduced and the reduced sample was $\sim 48.5$ $T$. This field value is typical of fine-grained goethite(22). The broad distribution with an average field of 43-44 $\mathrm{T}$ was assigned to goethite of lower crystallinity. This assignment is consistent with Ranourt et al. (23) who assigned a distribution of HFDs in annite samples to a mixture of hematite and poorly crystalline Fe oxides. The decrease in the intensity of the broad component after the bioreduction indicated that the poorly crystalline fraction of goethite was preferentially reduced by the bacteria.

TEM Observations. TEM analyses of CN32-illite suspensions in the presence of AQDS revealed close associations between illite and bacterial cells 1 day after inocculation (Figure 5, upper right). As reduction proceeded (by day 7), amorphous material with the chemical composition of illite as determined by EDS (data not shown) appeared to have developed at the cell-illite interface, and the illite particles not adjacent to the cell surfaces were crystalline, as revealed 

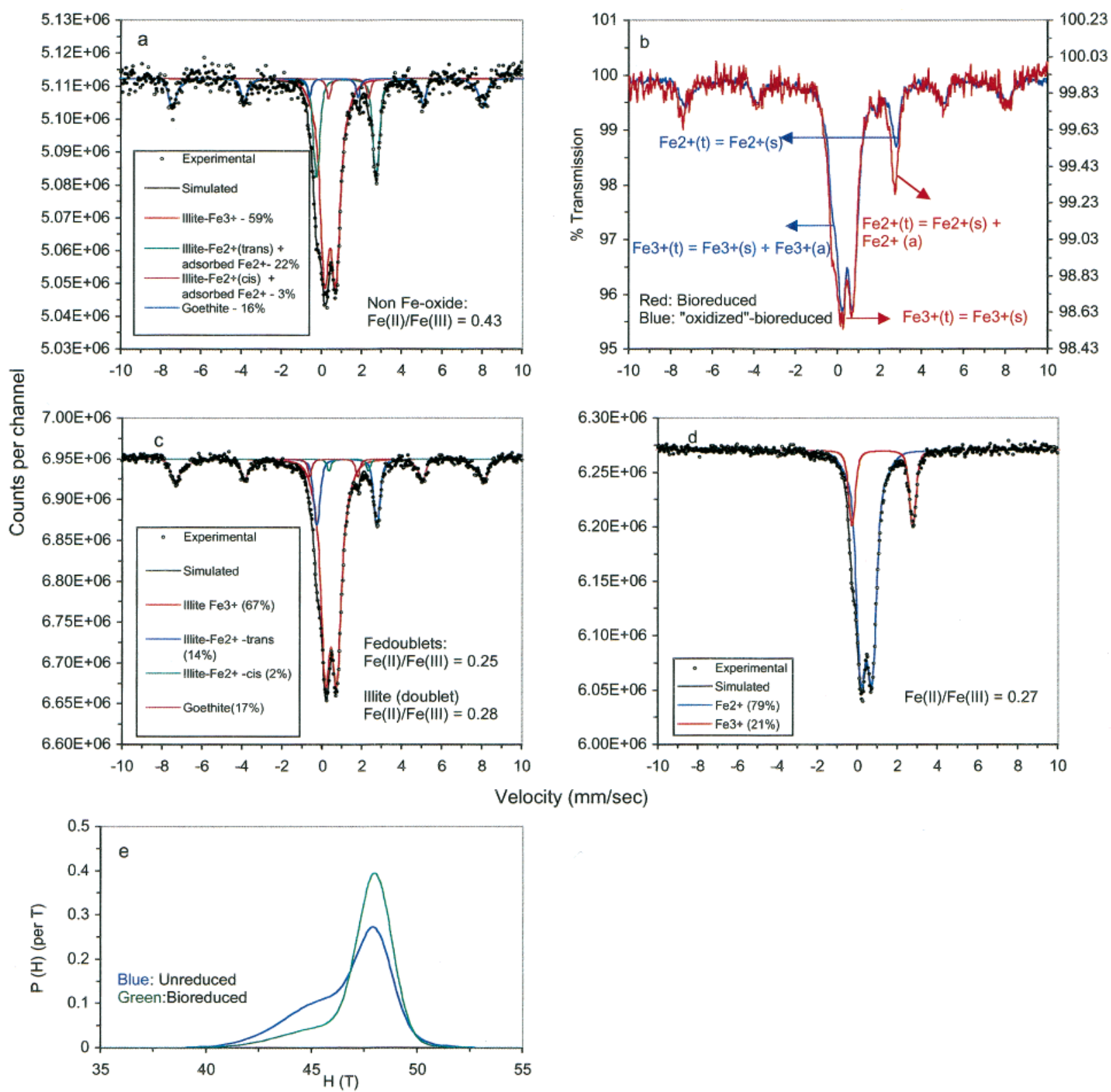

FIGURE 4. (a) The Mossbauer spectrum of the bioreduced material (the treatment with AQDS) at $77 \mathrm{~K}$; (b) assignment of the central and side doublets for the bioreduced and reoxidized samples, (c) the Mossbauer spectrum of the reoxidized sample, (d) the M ossbauer spectrum of the DCB-treated sample, and (e) hyperfine field distribution of goethite (before and after bioreduction). Show $n$ in the inset boxes of Figure $4 a, c, d$ are fractions of Fe in illite and goethite obtained from modeling of the experimental spectra. The percentages of Fe in goethite and illite are relative to the total Fe in the remaining solids. Because there $w$ as a fraction of Fe in aqueous solution, these percentages should be recalculated relative to the total Fe (including aqueous portion) to make meaningful comparisons with the corresponding values for the starting sample.

by lattice fringes (lower left-hand part of Figure 6). The internal structure of the cell was not visible, suggesting that the cell was no longer viable and had lost its cytoplasmic contents or was poorly stained. It was also possible that the resin may have detached from thehard mineral crust, causing a hole inside the cell. These illite-cell associations were commonly observed in TEM images. The thickness of the amorphous material at the interface appeared to be variable from one cell to another and appeared to be related to the nature of the enclosed cell. More particles appeared to be associated with the stained cells (Figure 5), whereas those cells that appeared to be dead or plasmolyzed had little particlesassociated with them (Figure 7). The active reduction process and clay dissolution, in addition to active cells maintaining their surface charge, may have contributed to this variablethickness. The boundary between the crystalline illite and amorphous material varied, ranging from distinct

(lower left-hand part of Figure 6) to more gradual transitions (upper and lower right-hand parts of Figure 6). At day 30, bacterial cells were generally smaller in size, and fewer were in contact with illite (Figure 7). A light, halolike region developed. Thistype of feature has been commonly observed in cultures of Shewanella algae incubated in suspensions with $\mathrm{U}(\mathrm{VI})$ and $\mathrm{Mn}$ oxides (Alice Dohnalkova, personal communication), possibly as a result of detachment of outer membranes caused by cell plasmolysis.

There was an apparent change in illite crystal morphology that paralleled microbial Fe(III) reduction (Figures 8 and 9). The illite particles in the unreduced sample displayed a predominant needlelike morphology (Figure 8) with a singlecrystal SAED pattern showing $1 \mathrm{M}$ polytype and $\mathrm{d}_{(001)}=10$ $\AA$. In some needles, there appeared to be striations perpendicular to the axis. In contrast, $\sim 10-15 \%$ of the illite crystals in the reduced sample displayed euhedral, platelike 


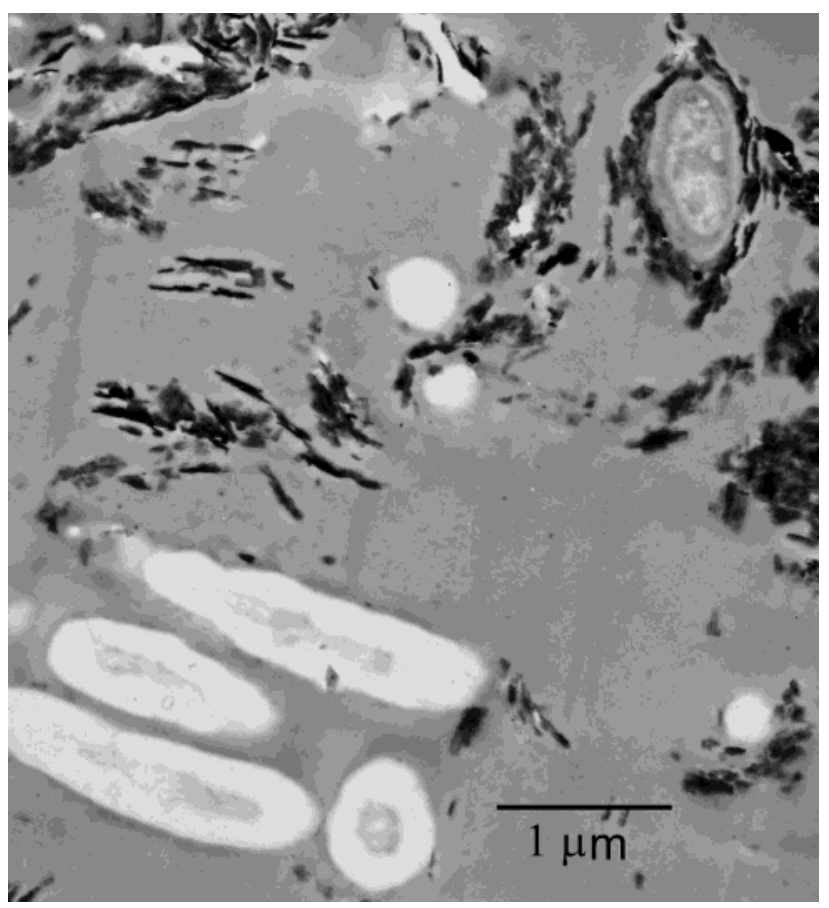

FIGURE 5. TEM image showing a bacterial cell that was coated by illite particles (upper right) shortly after the experiment was started (day 1). M any other cells w ere not coated, how ever (low er left).

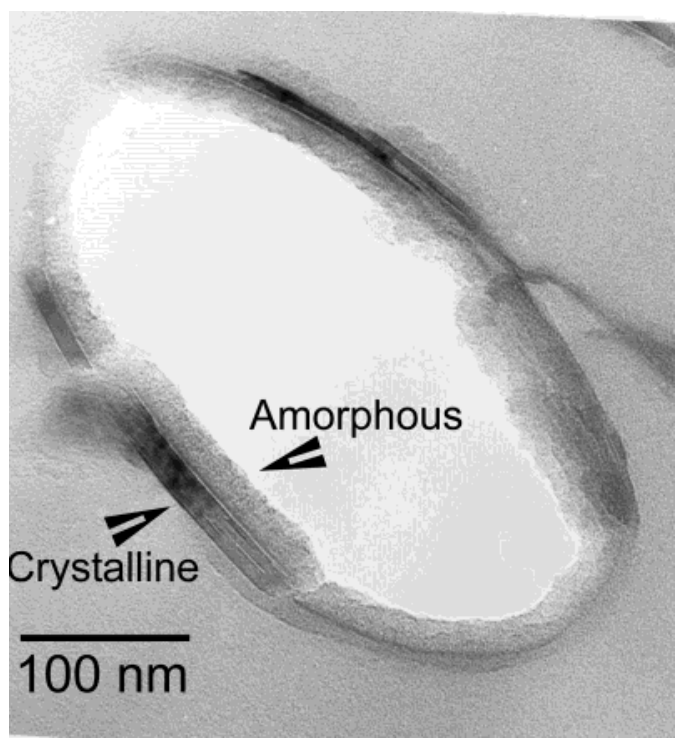

FIGURE 6. Bacterial cell coated by illite particles. The illite particles at the cell-illite interface appear amorphous, whereas those at external rims are crystalline, as evidenced by the presence of lattice fringes.

morphology (Figure 9). The EDS analyses did not detect any compositional differences, however, between the platelike and needlelikecrystals. Goethiteand illitewere the only solids observed in the bioreduced sample, and no other Fecontaining solids, such as siderite, were detected.

\section{Discussion}

HCl Extraction Efficiency. The $0.5 \mathrm{~N} \mathrm{HCl}$ extractable Fe(II) would include soluble and adsorbed $\mathrm{Fe}(\mathrm{II})$ and any other $\mathrm{Fe}(\mathrm{II})$ associated with biogenic mineral phases, such as siderite. The sum of aqueous and surface adsorbed Fe(II) concentrations (as measured by ammonium acetate extraction) was similar to the $0.5 \mathrm{~N} \mathrm{HCl}$-extractable Fe (Table 2),

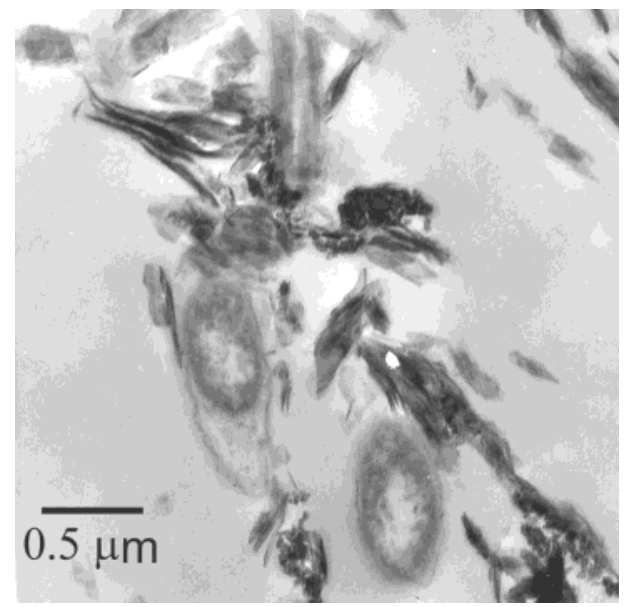

FIGURE 7. TEM image showing that bacterial cells decreased in their sizes near the end of the reduction experiment (day 30). The cells appear to have shrunk longitudinally, resulting in light, halolike regions.

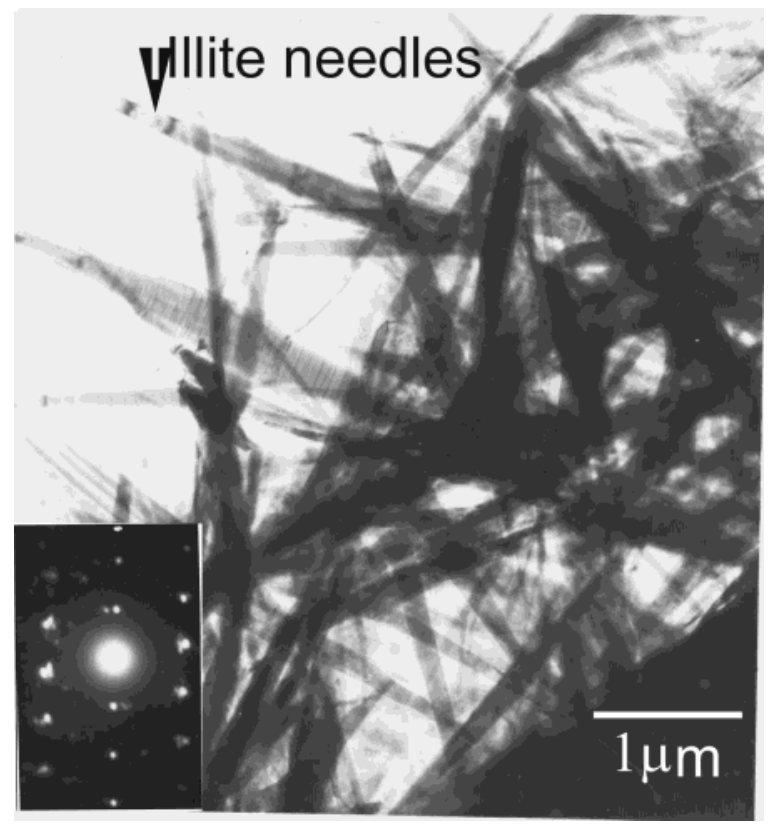

FIGURE 8. TEM image of illite in the starting sample showing needlelike crystals, typical of illite in sandstones. The SAED pattern show $s$ a single-crystal pattern with $1 \mathrm{M}$ polytype and $d(001)=10$ $\AA$. Some needles display strips perpendicular to the elongated direction of the needles. The morphology of the crystalline illite in Figure 7 should have been needlelike, because those crystals are inferred to be the starting illite.

suggesting that secondary mineral phases, such as siderite, did not precipitate and that $0.5 \mathrm{~N} \mathrm{HCl}$ extracted little or no $\mathrm{Fe}(\mathrm{II})$ associated with illite. Illite is generally not soluble in weak $\mathrm{HCl}$, and therefore, the $0.5 \mathrm{~N} \mathrm{HCl}$ extraction could have underestimated any increases in illite structural Fe(II) that may have resulted from AQDS-facilitated bioreduction. The TEM analyses indeed suggest that some fraction of illite ( 10-15\%) was morphologically transformed, possibly as a result of bioreduction.

Microbial Reduction of Illite and Goethite. A mixture of goethite and illite in the starting material complicated the determination of the extent of reduction of Fe(III) associated with each mineral phase. At the same time, it provided an opportunity to evaluate the relative microbial reducibility of $\mathrm{Fe}(\mathrm{III})$ associated with these two phases under competitive conditions. Several lines of evidence suggest that Fe(III) 


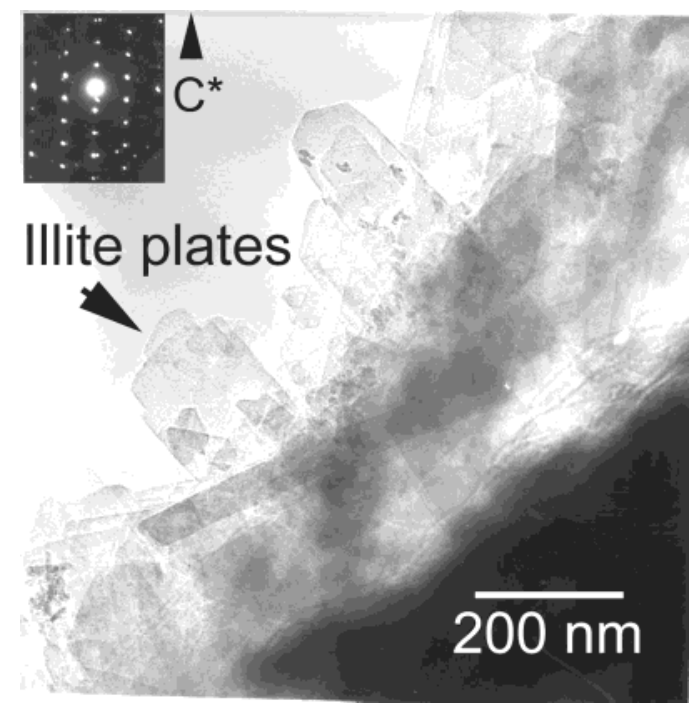

FIGURE 9. TEM image of illite in the bioreduced sample showing platelike crystals. The SAED pattern show s a single-crystal pattern, again with $1 \mathrm{M}$ polytype and $d(001)=10 \AA$.

associated with both goethite and illite was reduced by $\mathrm{S}$. putrefaciens CN32.

The bioproduced Fe(II) was partitioned between aqueous and surfaceadsorbed Fe(II). The decrease in theFe(II) doublet in the Mössbauer spectra of the bioreduced sample upon reoxidization (i.e., Figure 4c) strongly indicates the presence of an adsorbed $\mathrm{Fe}(\mathrm{II})$ species that was labile to oxidation. The oxidation of this adsorbed Fe(II) resulted in adsorbed $\mathrm{Fe}(\mathrm{III})$. The reoxidation experiment allowed determination of the $\mathrm{Fe}(\mathrm{II}) / \mathrm{Fe}(\mathrm{III})$ ratio for illite in the bioreduced sample. The derived ratio of 0.28 is similar to that for illite in the DCB-reduced samples (0.27) and suggests that (a) bacterial reduction resulted in an increase in the illite $\mathrm{Fe}(\mathrm{II}) / \mathrm{Fe}(\mathrm{III})$ ratio from 0.22 to 0.28 and (b) bacteria reduced thestructural $\mathrm{Fe}$ (III) of illite to a extent similar to that by a chemical reductant (dithionite). Theincrease in theilliteFe(II)/Fe(III) ratio as a result of bioreduction wasalso observed in sediment samples from subsoils from DOE's Oak Ridge site in eastern Tennessee that were enriched with illite (Zachara et al., in preparation).

TEM observations suggest that some of the starting, needlelike illite crystals were transformed into platelike crystals during bioreduction. It is not clear at present which mechanisms were involved to trigger such a transformation and whether they were related to Fe(III) reduction, and we speculatethat illitedissolution or reprecipitation might have been involved. Illite dissolution rates have been reported to vary widely, depending on $\mathrm{pH}$. At $\mathrm{pH} 6$ and $25^{\circ} \mathrm{C}$, the dissolution rate ranges from $\sim 4 \times 10^{-12} \mathrm{~mol} \mathrm{~m}^{-2} \mathrm{~s}^{-1}$ (24) to $6 \times 10^{-15} \mathrm{~mol} \mathrm{~m}^{-2} \mathrm{~s}^{-1}$ (25). Evaluations of the extent of illite dissolution in our experimental time frame require determinations of crystal size of illite in the starting material. Threedimensional crystal size of illite is difficult to measure precisely, even by TEM; some approximation can be made, however. Assuming an illite density of $2.8 \mathrm{~g} \mathrm{~cm}^{-3}$, a parallelepiped shape, and the most rapid of the reported dissolution rates, the minimum time for dissolution is 171 $\mathrm{d}$ to dissolve an illite crystal of $4 \mu \mathrm{m} \times 0.1 \mu \mathrm{m} \times 0.1 \mu \mathrm{m}$ in size. On the basis of measurements from 40 to 50 TEM images, this crystal size is typical of illite in the starting sample. At $\mathrm{pH} 2.9$ and $25^{\circ} \mathrm{C}$, Feigenbaum and Shainberg (25) calculated theillite dissolution rate to be $2.4 \times 10^{-10} \mathrm{~mol} \mathrm{~m}^{-2} \mathrm{~s}^{-1}$. Using this rate, it is estimated that it would take $\sim 1.7 \mathrm{~d}$ to dissolve an illite crystal of the samesize. It would take much less time to dissolve a portion of such a crystal in both cases. These calculations indicate that it is possible to dissolve some illite within our experimental time frame, especially when the $\mathrm{pH}$ is acidic. An acidic pH could have existed in microenvironments when bacterial cells wereactively metabolizing (Figure 6). Acidic functional groups on cell surfaces, such as exopolysaccharides, could also have contributed to illite dissolution. Considering the similar width and composition of illite crystals in the starting and bioreduced samples (Figures 8 and 9), the platelikeillitecrystals in the bioreduced sample could have been a product of along-layer dissolution of those needlelike crystals observed in thestarting material. It is well-established that the silicate mineral dissolution rate is different, depending on crystal lographic orientation, and such a differential dissolution can have a similar effect as crystal growth producing euhedral crystals (26).

Relative Reducibility of Goethite and Illite. There have been few studies comparing the relative reducibility of Fe oxides and Fe silicates by Fe-reducing bacteria. Kostka et al . (2) studied microbial reduction of Fe(III) in amorphous Fe oxides, goethite, smectite, and magnetite and found that smectite and goethite were reduced to similar extents by $\mathrm{S}$. putrefaciens MR-1, whereas both were less reducible than amorphous Fe(III), but more so than magnetite. Although illite and smectite have the same basic layer structure (2:1 phyllosilicates), illite has larger diffracting domains, with a more compact structure and fewer structural defects (less surfacearea) $(9,10)$, with an implication that Fe(III) associated with illiteis more difficult to reduce by bacteria or chemically. However, the simultaneous reduction of goethite and illite was not entirely unexpected, especially considering that the starting sample was dominated by illite with a minor amount of goethite so that many bacterial cells were in contact with illite particles (Figs 5, 6).

Role of AQDS. Mössbauer data showed that the bacteria were capableof reducing Fe(III) in poorly crystallinegoethite (Figure 4e) when reduction was facilitated by AQDS. Although it has been observed in previous studies that AQDS can enhancetherateand extent of bioreduction of $\mathrm{Fe}^{3+}$ in various Fe oxides $(14,15,18,27,28)$, this study has demonstrated that bioreduction of both goethiteand illite wassignificantly enhanced by AQDS. The active sites for electron transfer in illite and goethite may be located in size domains below the nominal size of the bacteria, limiting direct contact between bacteria and reduction sites. The coating of cells by illite may havelimited the potential with goethiteto an even greater extent.

Implications for Biogeochemical Transformations. Mutual interactions between bacteria and illite have important implications for both bacteria and illite. Illite provides nutrients and growth habitats for bacteria, and bacterial activity can influence physical and chemical properties of illite. A full evaluation of the extent of bacteria-illite interactions must consider both microbiological (microbial abundance, diversity, and activity) and geochemical (electron acceptor, donor, and shuttling compounds) variables. These types of data are obtainable only through carefully planned efforts, but this study defines potential mechanisms for focused future research opportunities.

The ability of bacteria to use Fe(III) in crystalline illite as the electron acceptor has important implications for delineating microbial survival mechanism in argillaceous rocks, especially in the subsurface, where Fe(III) associated with illite represents a dominant electron acceptor. Although the rates of in situ iron-reducing activity are not easily determined, our laboratory-based evidence suggests that it is feasible for subsurface bacteria to couple oxidation of $\mathrm{H}_{2}$ with reduction of $\mathrm{Fe}(\mathrm{III})$ associated with sedimentary illite when electron shuttling compounds, such as humic acids, are present.

Illite is ubiquitous in sedimentary basins (4) and forms as a reaction product of smectite as sediments are buried at 
increasing temperature and pressure $(9,10)$. Illite can also form in pore spaces of sandstones during diagenesis, destroying rock porosity and permeability and affecting petroleum migration. Because of its widespread occurrence, microbial activities that alter illite composition, structure, and stability would haveimportant implications for geological processes involving illite. In this study, we have shown that subsurface bacteria can reduce Fe(III) associated with illite structure and possibly dissolve illite crystals with which cells are in contact. The extent of microbial dissolution of illite in natural environments would depend on many variables. One important variable is humic acid concentration. If its concentration is limited in subsurface environments, the extent of microbial dissolution may be localized. However, certain metal-reducing bacteria have been shown to be capable of producing their own electron shuttles $(29,30)$, alleviating the need for external electron shuttles. Illite dissolution is also of environmental significance. Clay minerals such as illite have large surface areas, and tend to adsorb inorganic and organic contaminants (31). Dissolution of clay minerals by bacteria would mobilize these contaminants in soils and aquifers (32).

Folk and Lynch (33) discovered numerous bead-shaped nanobacterial bodies ( $0.1 \mu \mathrm{m}$ wide) on illite/smectite and illite flakes from Frio sandstones of the Gulf of Mexico sedimentary basin (Oligocene Frio Formation), and the authors hypothesized that these nanometer-sized bacteria played an active role in clay transformation and precipitation. If true, our laboratory-based results would be consistent with their observations on natural samples. However, beforesuch conclusions could be confirmed, more analyses would be required.

\section{Acknowledgments}

The authors are grateful to Ms. Alice Dohnalkova and Dr. Richard Edelmann for their help in TEM sample preparation. Acknowledgment is made to the donors of the Petroleum Research Fund, administered by the ACS, for support (or support in part) of this research. Mössbauer and XRD measurements were performed within the DOE/OBER Environmental Molecular Sciences Laboratory user facility. Pacific Northwest National Laboratory (PNNL) is operated for the U.S. Department of Energy by Battelle Memorial Institute under Contract DE-AC06-76RLO 1830. We are grateful to three anonymous reviewers for their valuable comments and suggestions.

\section{Literature Cited}

(1) Stucki, J. W. In Iron in Soils and Clay Minerals; Stucki, J. W., Goodman, B. A., Schwertmann, U., Eds.; Elsevier: Dordrecht, Netherlands, 1998

(2) Kostka, J. E.; Wu, J.; Nealson, K. H.; Stucki, J. W. Geochim. Cosmochim. Acta 1999, 63, 3705-3713.

(3) Boone, D. R.; Liu, Y.; Zhao, Z.; Balkwill, D. L.; Drake, G. R.; Stevens, T. O.; Aldrich, H. C. Int. J. Sys. Bacteriol. 1995, 45, 441448.

(4) Onstott, T. C.; Phelps, T. J.; Colwell, F. S.; Ringelberg, D.; White, D. C.; Boone, D. R.; McKinley, J. P.; Stevens, T. O.; Long, P. E.;
Balkwill, D. L.; Griffin, W. T.; Kieft, T. Geomicrobiology 1998, 15, 353-385.

(5) Lovley, D. R.; Kashefi, K.; Vargas, M.; Tor, J. M.; Blunt-Harris, E. L. Chem. Geol. 2000, 169, 289-298.

(6) Kashefi, K.; Holmes, D. E.; Reysenbach, A. L.; Lovley, D. R. Appl. Environ. Microbiol. 2002, 68, 1735-1742.

(7) Kostka, J. E.; Stucki, J. W.; Nealson, K. H.; Wu, J. Clays Clay Miner. 1996, 44, 522-529.

(8) Kostka, J. E.; Haefele, E.; Viehweger, R.; Stucki, J. W. Environ. Sci. Technol. 1999, 33, 3127-3133.

(9) Dong, H.; Peacor, D. R. Clays Clay Miner. 1996, 44, 257-275.

(10) Dong, H.; Peacor, D. R.; Freed, R. L. Am. Mineral. 1997, 82, 379-391.

(11) Huang, W.-L.; Longo, J. M.; Pevear, D. R. ClaysClay Miner. 1993, $41,162-177$

(12) Stookey, L. L. Anal. Chem. 1970, 42, 779-781.

(13) Lovley, D. R.; Phillips, E. J. P. Appl. Environ. Microbiol. 1986, $52,751-757$

(14) Zachara, J. M.; Fredrickson, J. K.: Li, S.-W.; Kennedy, D. W. Smith, S. C.; Gassman, P. L. Am. Mineral. 1998, 83, 1426-1443.

(15) Fredrickson, J. K.; Zachara, J. M.; Kennedy, D. W.; Dong, H.; Onstott, T. C.; Hinman, N. W.; Li, S. M. Geochim. Cosmochim. Acta 1998, 62, 3239-3257.

(16) Jackson, M. L.; Lim, C. H.; Zelanzy, L. W. Methods of Soil Analysis 2nd ed.; Part 1: Physical and Mineralogical Methods; American Society of Agronomy-Soil ScienceSociety of America: Madison, WI, 1986.

(17) Fredrickson, J. K.; Zachara, J. M.; Kukkadapu, R. K.; Gorby, Y. A.; Smith, S. C.; Brown, C. F. Environ. Sci. Technol. 2001, 35, 703-712.

(18) Kukkadapu, R. K.; Zachara, J. M.; Smith, S. C.; Fredrickson, J. K.; Liu, C. X. Geochim. Cosmochim. Acta 2001, 65, 2913-2924.

(19) Rancourt, D. G.; Ping, J. Y. Nucl. Instrum. Methods Phys. Res., Sect. B 1991, 58, 85-97.

(20) Diamant, A.; Pasternak, M.; Banin, A. Clays Clay Miner. 1982, $30,63-66$.

(21) Komadel, P.; Lear, P. R.; Stucki, J. W. Clays Clay Miner. 1990, 38, 203-208.

(22) Murad, E. Hyperfine Interact. 1998, 117, 39-70.

(23) Rancourt, D. G.; Mercier, P. H. J.; Cherniak, D. J.; Desgreniers, S.; Kodama, H.; Robert, J. L.; Murad, E. Clays Clay Miner. 2001, $49,455-491$.

(24) Heydemann, A. Geochim. Cosmochim. Acta 1966, 30, 995-1035.

(25) Feigenbaum, S.; Shainberg, I. Soil Sci. Soc. Am. Proc. 1975, 39, 985-990.

(26) Awad, A.; Koster van Groos, A. F.; Guggenheim, S. Geochim Cosmochim. Acta 2000, 64, 1765-1772.

(27) Dong, H.; Fredrickson, J. K.; Kennedy, D. W.; Zachara, J. M.; Kukkadapu, R. K.; Onstott, T. C. Chem. Geol. 2000, 169, 299 318.

(28) Fredrickson, J. K.; Kostandarithes, H. M.; Li, S. W.; Plymale, A E.; Daly, M. J. Appl. Environ. Microbiol. 2000, 66, 2006-2011.

(29) Newman, D. K.; Kolter, R. Nature 2000, 405, 93-97.

(30) Nevin, K. P.; Lovley, D. R. Geomicrobiol. J. 2002, 19, 141-159.

(31) Siantar, D. P.; Feinberg, B. A.; Fripiat, J. J. Clays Clay Miner. 1994, 42, 187-196.

(32) Francis, A. J.; Dodge, C. J. Environ. Sci. Technol. 1990, 24, 373378

(33) Folk, R. L.; Lynch, F. L. J. Sed. Res. 1997, 67, 583-589.

Received for review September 4, 2002. Revised manuscript received January 10, 2003. Accepted January 21, 2003.

ES020919D 